\title{
Årsberetning 1974-1975
}

Grundtvig-Selskabets årsmøde blev i 1974 holdt i København, i Vartov, hvor selskabets sekretær, adjunkt mag. art. Hellmut Toftdahl behandlede det spørgsmål: "Var Grundtvig mystiker?" Foredraget er trykt i samme årgang af Grundtvig-Studier ("Grundtvig og mystikken"). Efter foredraget fulgte en kort debat. Om aftenen talte universitetslektor Jørgen Elbek i tilslutning til sin bog "Grundtvigs atten prøveår «; også dette foredrag efterfulgtes af en kort debat. Næste formiddag besøgte selskabet Christianskirken, og professor dr. phil. Christian Thodberg talte om Grundtvigs prædikener og salmer fra 1837, da Grundtvig prædikede $\mathrm{i}$ denne kirke. (Dette foredrag er trykt af selskabet Dansk Kirkesang i dettes årsskrift.) Selskabet besøgte også Vor Frelsers Kirke, hvor vi blev modtaget af pastor Karen Horsens, der viste os kirken og talte om Grundtvigs virksomhed der.

Arbejdet med at tilvejebringe en oversættelse af et udvalg af Grundtvigs skrifter til engelsk er i det forløbne år fortsat. Det er lykkedes at finde en oversætter og at opnå støtte til en oversættelse af 200 sider fra Aarhus Universitet; også oversætteren har været knyttet til Aarhus Universitet. Men desværre har den amerikanske komité, efter en kort brevveksling, i juli 1975 meddelt vort arbejdsudvalg, at den har modtaget et tilbud fra det amerikanske forlag, den samarbejder med, om at udgive et bind oversættelser af komiteens medlemmer, som vort arbejdsudvalg ikke har fạet lejlighed til at gennemse. Komiteen ønsker os til lykke med den modtagne støtte til vort oversættelsesarbejde, men har alligevel besluttet at fortsætte sit arbejde alene. Vanskeligheden for Grundtvig-Selskabet består nu i at finde et forlag til at udgive de oversættelser, som vi har fået støtte til. Vi håber stadig, at det vil lykkes. 
Regnskabet har efter kontorchef Garsdals død midlertidig været overtaget af selskabets sekretær, der er blevet bistået af timelærer, stud. mag. Mette Truelsen, som også har deltaget i forretningsudvalgets seneste møde. Selskabets adresse er stadig Vartov, hvorfra fru Elisabeth Jensen ekspederer vore bøger og udsender vore meddelelser til medlemmerne. Selskabet har herfra $\mathrm{i}$ det forløbne år udsendt subskriptionsindbydelse på to bøger: P. G. Lindhardts Konfrontation og Andreas Haarders disputats om Beowulf.

William Michelsen

Ved årsmødet i oktober 1975 blev det besluttet p.gr. af den almindelige prisudvikling at hæve kontingentet med $5 \mathrm{kr}$., således at det nu udgør $40 \mathrm{kr}$. (30 kr. for studerende). 